FILOZOFIA

Roč. 75, 2020, č. 2

DOI: https://doi.org/10.31577/filozofia.2020.75.2.3

\title{
KONVERGENCIE FENOMENOLÓGIE, PRAŽSKÉHO ŠTRUKTURALIZMU A UMELECKEJ TVORBY. PRÍSPEVOK KU GENEALÓGII FENOMENOLÓGIE V STREDOEURÓPSKOM PRIESTORE
}

\author{
JAROSLAVA VYDROVÁ, Filozofický ústav Slovenskej akadémie vied, Bratislava, SR
}

VYDROVÁ, J.: Convergence of Phenomenology, Prague Structuralism and Art Creation. Genealogy of Phenomenology in Central European Context

FILOZOFIA, 75, 2020, No 2, pp. $109-120$

\begin{abstract}
In the framework of presenting a genealogy of phenomenological philosophy in the Central European context, the article will demonstrate a convergent relation between phenomenology and Prague structuralism and will examine specific topics which derive from this relation. In the first part we address the concepts of attitude, constitution and language, and, in the second, the "situation" of artistic creation as well as the reception of works of art. In this context we also introduce a relevant concrete example of the creative artistic process that sheds light on these topics. From this thematic configuration - in the third part - will follow the question of the scope of the phenomenological method as well as suggestions for the possible interdisciplinary development of phenomenology.
\end{abstract}

Keywords: Genealogy of phenomenology - Edmund Husserl - Prague structuralism Phenomenological method - Avantgarde

\section{Úvod}

Výskum dejín fenomenologického hnutia v stredoeurópskom a východoeurópskom prostredí je $\mathrm{v}$ súčasnosti jednou $\mathrm{z}$ dynamicky sa vyvíjajúcich oblastí záujmu historikov ideí aj fenomenológov. Výsledky tohto skúmania pomáhajú odkrývat' nové súvislosti Husserlovej filozofie a jeho priamych predchodcov a spolupútnikov, ako aj nové vzt'ahy s paralelne pôsobiacimi filozofickými smermi, a zároveň toto skúmanie prekračuje čisto historiografický výskum. ${ }^{1} \mathrm{U}$ nás motivuje tento návrat aj skutočnost',

\footnotetext{
${ }^{1}$ Spomeňme základné možnosti tohto skúmania: dá sa rozdelit' podl'a konkrétnych oblastí, od matematiky, logiky, psychológie až po etiku a estetiku, fenomenológiu možno sledovat' vo vzt'ahoch k filozofickým prúdom alebo školám (novokantovci, husserlovské školy a pod.), kde sa jednotlivé línie riešenia problémov odvíjajú od konkrétnych spoluprác alebo dobových diskusií medzi ich predstavitel'mi. Jednou z možností je skúmat' fenomenológiu v kontextoch toho, ako sa vyvíjala v rôznych tradíciách spojených s vlastným kultúrnym, spoločenským a politickým priestorom. Osobitne
} 
že mnohé miesta dobového fenomenologického výskumu nie sú na Slovensku známe a objavujú sa nové možnosti pôsobenia fenomenológie v inšpiratívnej a produktívnej spolupráci s inými disciplínami.

Dôvodov, prečo sa venovat' tomuto výskumu, je preto viac a patria k nim aj osobité podmienky filozofického myslenia $\mathrm{v}$ našom regióne, $\mathrm{z}$ ktorých fenomenológia vychádzala, v ktorých bola zakorenená, ktorými sa inšpirovala, alebo sa s nimi konfrontovala. $\mathrm{K}$ formovaniu týchto podmienok prispelo aj pôsobenie dvoch významných krúžkov Pražského lingvistického krúžku a Pražského filozofického krúžku. Z tejto „situácie fenomenológie“ vyplýva viacero špecifik, ktoré sa týkajú tém a oblastí výskumu. Postupne preto predstavíme vybrané príklady pôsobenia a vplyvu medzi štrukturalizmom a fenomenológiou, ktoré sa odvíjajú najmä od koncepcie postoja, konštitúcie a jazyka, ktorým sa budeme venovat' v prvej časti textu. $\mathrm{V}$ druhej časti na to nadviažeme otázkou recepcie umenia, ktorú $\mathrm{v}$ tejto súvislosti rozpracoval Zdeněk Mathauser, a predstavíme aj jeden konkrétny príklad, na ktorom sa dá poukázat' na vzájomné pôsobenie medzi fenomenológiou a umeleckou tvorbou. Zároveň si položíme otázku, aké závery z toho vyplývajú pre fenomenologickú metódu a pre interdisciplinárne možnosti fenomenológie $\mathrm{v}$ súčasnom diskurze, a tejto téme sa budeme venovat' $\mathrm{v}$ tretej časti textu.

\section{Možnosti zblíženia: postoj, jazyk, teória vzt’ahov}

Prvá oblast', ktorou sa budeme zaoberat', vychádza pôvodne z genealógie pražského štrukturalizmu a jeho prienikov s fenomenológiou. Budeme nadväzovat' na práce Elmara Holensteina a Davida Hermana, ${ }^{2}$ ktorí sledovali konvergencie a vplyvy medzi oboma smermi, pričom Holensteinov prístup možno označit' za otvorenejší, pretože nachádza niekol'ko produktívnych súvislostí, zatial' čo Herman identifikuje ich vzájomný vplyv skôr ako čiastkový.

Koncepcie Romana Jakobsona a Edmunda Husserla majú viaceré styčné body, ktoré vychádzajú jednak zo spoločne nastoleného kritického postoja k dobovým (pozitivisticky a kauzálne orientovaným) schémam poznania, jednak sú motivované hladaním nového prístupu $\mathrm{k}$ riešeniu problémov, ktorý má byt' nezávislý od vopred daných teórií a interpretácií. Spoločnými oblast’ami záujmu, ktoré sa u oboch myslitel’ov prekrývajú, sa stávajú pozícia subjektu, jazyka a teória vzt’ahov, časti a celku, pričom svoju úlohu

stredoeurópskemu a východoeurópskemu výskumu sa venuje organizácia Central and East European Society of Phenomenology, ako aj publikácie Horizon 5 (1), 2016, Studies in East European Thought 69 (1), 2017, Mervart (2013) a i. V tejto súvislosti možno spomenút' práce, ktoré vznikli u nás: monotematické číslo časopisu Filozofia 61 (1), 2006, ktoré bolo venované slovenskej a českej fenomenológii v stredoeurópskom kontexte, príspevky v Analecta Husserliana XXVII (1989) a individuálne štúdie V. Leška, J. Siváka, F. Matejova, V. Bakoša a i.

${ }^{2}$ Elmar Holenstein je švajčiarsky filozof a lingvista, ktorý okrem iného edične pripravil vydanie prvého dielu Husserlových Logických skúmaní. David Herman je americký lingvista, ktorý sa venuje lingvistickej a filozofickej analýze literárnych diel. 
tu zohráva aj osobitý dôraz, ktorý kladú práve českí a ruskí štrukturalisti na isté časti Husserlovej fenomenológie - prvé, tretie a štvrté Logické skúmanie (Holenstein 1976, 56 - 58, čes. 100 - 102, Husserl 2010). Prienikov by sa dalo nájst' viac, a to aj v iných kontextoch a neskoršom období, pričom v určitých aspektoch nadobúdajú dominantnejšiu podobu (pri témach, ako sú časové vedomie a intersubjektivita). ${ }^{3}$ Kritika psychologizmu ako vo fenomenológii, tak aj v štrukturalizme bola len začiatkom skúmania, ktoré sa tematicky rozvetvovalo do viacerých oblastí, vychádzajúc z nového prístupu k subjektívnym priebehom poznania, ktorý nemá za ciel' subjekt eliminovat' alebo nahradit', ale nanovo uchopit' jeho podmienky v súvislosti s procesmi aktívnej a pasívnej konštitúcie, kde majú svoju podstatnú úlohu vedomé aj nevedomé aspekty, a zároveň aj hladisko druhého subjektu.

Prvú rovinu porovnania, na ktorej sa stretáva štrukturalistický a fenomenologický prístup, môžeme spojit' s pojmom postoj (Einstellung), respektíve s jeho zmenou. Práve zmena postoja umožňuje, aby sa v jazyku rozvinuli aj jeho neobvyklé funkcie, ku ktorým patrí napríklad poetická funkcia. Vo fenomenológii je postojová tematika rovnako klúčová, pretože umožňuje prechod od prirodzeného postoja $\mathrm{k}$ fenomenologickému, zo sféry neproblémového, známeho, každodenného prežívania a poznania $\mathrm{k}$ takej sfére, $\mathrm{v}$ ktorej sa otvára pole javenia fenoménov na základe ich spôsobu danosti. Postoj plní v oboch prípadoch podobnú funkciu: premieňa, vymieňa, prestavuje pohl'ad tým, že vyrad'uje z platnosti tézy, ktoré utvárajú prirodzený, bežný postoj. Známy, familiárny postoj sa pritom problematizuje, vzniká potreba začat' sa pozerat' iným, novým spôsobom. Holenstein nachádza paralelu medzi pozíciou poézie pri skúmaní jazyka a pozíciou telesnosti v skúmaní fenomenológie. Telesnost' v každodennom živote vystupuje často inštrumentálne, z čoho vyplýva aj inštrumentálny prístup $\mathrm{k}$ telu, ktorý prevažuje $\mathrm{v}$ teoretických a praktických postupoch. No fenomenologická analýza ukazuje, že telesnost' je ovel’a štruktúrovanejší a komplexnejší fenomén, ktorý sa prejavuje v podobe takzvaného fyzického (Körper) a živého tela (Leib). Telesnost' nie je uzavretá vo fyzickom tele a vo funkcii nástroja, ale je výrazom života subjektivity, jej intencií a premien. Tie prekračujú fyziológiu smerom k emocionalite, komunikácii, konaniu, expresivite, tvorbe a pod. Telesná schéma subjektivity sa odvíja od skúsenosti ako paradigmatického východiska vo fenomenológii ${ }^{4}$ - jednak od vnímania predmetu, jednak od skúsenosti druhého, teda intersubjektívnej situácie, čo

\footnotetext{
${ }^{3}$ Porov. Holenstein (1976, 20 a n.), Husserl (2006).

${ }^{4}$ Ako uvádza Husserl na začiatku Idei k čistej fenomenológii a fenomenologickej filozofii I: ,... prirodzené poznanie sa začína skúsenost'ou a zotrváva $v$ skúsenosti (Husserl 1976, 10, čes. 21). Porov. (Merleau-Ponty 2013).
} 
vytvára rôzne konfigurácie živého a fyzického tela (Körper im Leib alebo Leib im Körper) ${ }^{5}$

Zmena postoja, ktorá umožňuje, že sa v jazyku rozvíja poézia a že sa pri vnímaní fenomény odhalujú v spôsobe ich danosti na základe princípu dávania, ${ }^{6}$ je teda zmenou celkového zamerania, zmenou vedomia a apercepcie.

Ďalšou styčnou oblast'ou je jazyková konštitúcia sveta, ktorú Jakobson spája $\mathrm{s}$ tvorbou viet obsahujúcich subjekt a predikát. To sa napríklad u diet’ata, ktoré vie povedat' anekdotu, prejavuje tým, že sa „vyslobodzuje zo svojej aktuálnej situácie“, dokáže variovat' jej kontexty, pozriet' sa na situáciu aj mimo nej samej, zvládnut' ju (Holenstein 1976, 64 - 65, čes. 108 - 109). Možnost' štruktúrovat' situáciu, byt' v nej zainteresovaný a z odstupu ju vediet' posúdit', vychádza z konštitúcie, ktorá pracuje so spoludanost'ou implicitného pozadia, z ktorého sú vyzdvihované predmetnosti, významové súvislosti a aktivity subjektu. Ak niektoré zo zložiek konštitúcie v subjekte nefungujú, situácia sa prevracia do seba bez možnosti svojho rozvíjania. Zdravé diet'a, napríklad, vidí pred sebou predmety ako príležitost' na hru, usporiadanie, ako prekážku alebo otázku, no diet’a, ktoré má problém zorientovat' sa v situácii, nevidí súvislosti, vzt'ahy ani dôvod konat'.

Konštitúcia sveta je konštitúciou vzt’ahov, súvislostí časti a celku, ku ktorým nám otvára cestu jazyk. Tam, kde dochádza $\mathrm{k}$ nefunkčnosti pri použivaní slov, napríklad pri afázii, ${ }^{7}$ dochádza aj k rozpadu situácie, respektíve nedochádza $\mathrm{k}$ jej konštituovaniu. Ako príklad, ktorý vystihuje jadro tohto problému, možno uviest' fundáciu súvisiacu so vzt’ahmi opozície, respektíve pólovosti. Opozícia totiž nie je jednoduchým vylúčením jedného vo vzt'ahu k druhému, ale stát' oproti sebe obsahuje aj prvok zahrnutia - „vylúčená čast' opozície je však vo vedomí nevyhnutne spoluprítomná... Husserl pre mnohé fenomény, ktoré heglovsky orientovaní filozofi, ako aj istí francúzski štrukturalisti uchopujú pomocou oblúbeného páru ,prezencia - absencia‘, zaviedol terminologický pár ,prezencia aprezencia, prípadne komprezencia'. Dôraz sa kladie na spoludanost' toho, čo je vylúčené, vo vedomí“ (Holenstein 1976, 83 - 84, čes. 111). Dôvod, prečo je to tak, teda vychádza zo skutočnosti, že ide o opozíciu danú pre mňa. Zároveň tento vzt’ah opozície vo svojej

\footnotetext{
${ }^{5}$ Spomeňme skúmanie emocionality, gestikulácie či znakovania - túto oblast' zaujímavým spôsobom preskúmal J. Fulka (2017).

6 ,... že každý originárne dávajúci názor je zdrojom oprávnenia pre poznanie“(?) a že „,šetko, čo sa nám $v$, intuícii 'originárne ponúka (takpovediac vo svojej telesnej skutočnosti), treba chápat' jednoducho tak, ako sa to dáva, ale takisto len v hraniciach, v ktorých sa to dáva "(Husserl 1976, 51, čes. 56). ${ }^{7}$ Afáziou sa zaoberali napríklad vo filozofii M. Merleau-Ponty, v psychopatológii K. Goldstein, ako aj R. Jakobson v rámci lingvistiky, ktorý sa zároveň odvolával na Goldsteinove výskumy. Lingvistika sa zaoberá ,jazykom v akcii, jazykom v pohybe, jazykom v stave zrodu i jazykom v rozklade“ (Jakobson 1995, 55), a tak skúmanie porúch odhal'uje problémy pri jazykových operáciách v oblasti kombinácie a kontextualizácie, ako aj selekcie a substitúcie pri usporiadavaní znakov (porov. Jakobson 1995, 58 - 59).
} 
sebadanosti pretrváva na pozadí vo vedomí, z ktorého sa dá jeden prvok vyzdvihnút ako potvrdený a druhý ako negovaný. $\mathrm{K}$ tomuto vyzdvihnutiu dochádza na základe obsahových, teda kvalitatívnych momentov. $\mathrm{V}$ tomto bode sa Holensteinova analýza prekrýva aj s Husserlovou charakteristikou kontrastu a afektívneho reliéfu pri skúmaní súvislostí pasívnej syntézy a vnútorného časového vedomia (Husserl 1966), ktoré opisujú vyzdvihnutie z pozadia a afektívnu situáciu ako situáciu, pri ktorej sa nerozhoduje takpovediac len podl'a kvantitatívnej intenzity afekcie. Afekcie totiž nie sú neutrálne v tom zmysle, že sú súčast'ou preferencie, záujmu, pozornosti subjektivity. Tú možno, samozrejme, rozvrhnút' rôzne - napríklad sa podriad’ujeme aktuálnemu záujmu, tomu, o čo nám ide, alebo viac priestoru ostane pre neosobné alebo nevôl'ové zložky, ktoré sa podielajú na rozvrhovaní horizontu našich aktov a aktivít. Afektívna sila tak môže byt' aj výsledkom „vel'kosti, sily vyzdvihnutia“, aj výsledkom intenzity záujmu. „Je to predsa obmena intencionality ako prúdiaca intencionálna modifikácia... Plnost', nasýtenie kvality, diferencie v predmetnom obsahu sa konštituujú až v časujúcom prúde intencionálnych obmien. A jednota... je to, čo afikuje predmet záujmu vo všetkých svojich vlastných modoch" (Husserl 2014, 44 - 45). K čomu H. Peucker dodáva, že „len na základe tohto kvalitatívneho rozlíšenia v rámci sféry pasivity vedomia je pochopitel’né, prečo prichádza práve $\mathrm{k}$ týmto, a nie $\mathrm{k}$ nejakým iným intenciám Ja“ $(2008,6)$.

Jakobsonova koncepcia vhodne dopín̆a a konkretizuje Husserlovu konštitutívnu analýzu o kontext takzvaných „príznakových a bezpríznakových slov“, slov zužujúcich a rozširujúcich význam, respektíve stojacich v protichodných (pólových) vzt'ahoch. ${ }^{8} \mathrm{Ja}-$ kobson si totiž všímal, v akých vzt'ahoch vystupujú slová ako malý a vel'ký, blízko a d’aleko, nový a starý, úzky a široký a pod. Pri polarite v rovine fonetiky pri dištinktívnych príznakoch poukazoval na rozdiel ako kontrast a protiklad ako opozíciu (Jakobson 1991, 209). Holenstein sleduje, ako L. S. Vygotskij a Eva V. Clarková zase skúmali genézu osvojovania takých slov ako predtým a potom či zajtra a včera, ktoré sa nenachádzajú v neutrálnom, ale v hierarchickom postavení, resp. vo vzt’ahu následnosti. Ako sme spomínali, opozícia slov nie je len exklúziou, no nie je ani neutrálnym vymedzením. To sa ukazuje napríklad v týchto vetách: „Gerda má k Franzovi rovnako blizko ako k Jozefovi“ a „Gerda má k Franzovi rovnako d'aleko ako k Jozefovi“, kde vystupuje prvý vzt’ah ako bezpríznakový, pretože bez d’alších informácií nemožno určit', o aký vztah ide, no druhý prípad napovedá, že vzt'ah nebude až taký osobný (Holenstein 1976, 69, čes. 113). Holenstein používa príklady viacerých viet, aj takých, kde opozícia funguje inak v priestorových a inak v personálnych vzt’ahoch. Práve tieto špecifiká vyplývajú

\footnotetext{
${ }^{8}$ Bezpríznakové slová sa v jazyku diet’at’a vyskytujú ako prvotné, až neskôr dochádza k používaniu príznakových slov. Pri poruchách, ako je napríklad afázia, zase dochádza $\mathrm{k}$ narušeniu tvorby alebo porozumenia príznakovosti a naopak, $\mathrm{k}$ preferencii používat' bezpríznakové slová, respektíve $\mathrm{k}$ ich zamieňaniu alebo ambivalencii (Holenstein 1976, 68 - 73, čes. 112 - 117).
} 
z obsahovej a kontextovej analýzy ich aktívneho používania, učenia, alebo v prípade porúch ich zlyhaní.

Holenstein tak uzatvára pozorovanie súvislostí medzi pražským štrukturalizmom a fenomenológiou potvrdením ich afinity $\mathrm{v}$ podobe jedinečnej konfigurácie vzt’ahov medzi látkou a formou ako dynamického systému, založeného na „kvalitatívnych obsahových determinantoch“ (Holenstein 1976, 74 - 75, čes. 119).

Doplňme k tomu ešte analýzu Davida Hermana, ktorý v nadväznosti na Holensteina upozorňuje na možnosti zblíženia fenomenológie a pražského štrukturalizmu, hoci ich identifikuje skôr ako čiastočné alebo jednorazové a jeho postoj je v tomto smere menej „entuziastický“. Nachádza viaceré oblasti, kde sa oba smery rozchádzajú, no nakoniec konštatuje, že mali spoločný záujem nielen o pozitivistickú kritiku, ale vd'aka Gustavovi Špetovi prišlo aj na dôležité „obmieňanie“ metód a výmenu ideí smerom od fenomenológie k pražskému štrukturalizmu (Herman 2014, 121). ${ }^{9}$ Styčné body sa týkajú literárneho diela a Herman identifikuje vplyv a význam analýz Romana Ingardena v tom, že vyzdvihuje skúmanie, ,ktoré berie zároveň do úvahy text i kontext, štruktúru i funkciu“, a až to „môže poskytnút' skutočný vhl'ad do umeleckého literárneho diela“ (Herman 2014, 128).

\section{Reverzibilný vzt'ah fenomenológie a umenia}

Motívov, ktoré obojsmerne prechádzajú medzi fenomenológiou a pražským štrukturalizmom, je viacero, a špecifickým spôsobom sa dotýkajú problému danosti, umeleckého diela či estetickej funkcie (M. Jankovič, F. Vodička, P. Blažíček a i.). Samostatnou témou by v nadväznosti na Mukařovského bola problematika „sémantického gesta“. ${ }^{10} \mathrm{~V}$ nasledujúcej časti nadviažeme na analýzu literárneho diela, a to exemplárnym prípadom tvorivého prieniku s fenomenológiou, ktorý prinášajú analýzy Zdeňka Mathausera. Na viacerých príkladoch vzt'ahu avantgardného umenia, fenomenologických analýz a tém (napríklad ruského formalizmu, kubofuturizmu, a to najmä v súvislosti s poéziou, ale aj s výtvarnými dielami) totiž Mathauser ukazuje, ako sa v prvých dvoch desat'ročiach 20 . storočia v mnohom moderné i avantgardné umenie a fenomenológia „sprevádzali“, boli v rôznych aspektoch „obdobné“, ,Zvratné“, reverzibilné vo svojom pôsobení.

V texte Česká a ruská avantgarda a jejich filosofický průvodce si Mathauser ako prvú spoločnú oblast' všíma apsychologizmus, kritický postoj voči relativizmu pri interpretácii poznávania, vnímania či správania, zato sa rozvíjajú pokusy hladat' nový spôsob pri zobrazovaní a slovesnej tvorbe, ktoré sa odchyl’ovali od naturalistického či

\footnotetext{
${ }^{9}$ Herman zakladá svoju analýzu na Ingardenovej práci Umelecké dielo literárne a na prácach F. Vodičku. K súvislostiam okolo vplyvu G. Špeta porov. aj Holenstein $(1976,15)$.

${ }^{10} \mathrm{~V}$ našom kontexte sa tejto téme venoval M. Lipták (2007; 2013, 37, 173 a n.).
} 
empirického popisovania a psychologizujúceho pocit'ovania. Mathauser sa opakovane zaoberá fenomenologickou metódou, respektíve opisuje metodické gesto, ktoré sa skrýva v pozadí týchto iniciatív a „v ktorom je i nárok na výkon myslenia, i pokora voči myslenému“ (2006, 137, porov. aj 1999, 75, 80).

Toto metodické gesto zasahuje viacero rovín - týka sa jednak vzt’ahu k vnútorným, subjektívnym procesom, intencionalite vedomia, odhal'ovaniu toho, čo je implicitné, jednak dochádza $\mathrm{k}$ zásadnej zmene v prípade štatútu reality, ktorý sa vo fenomenológii problematizuje. Noeticko-noematická korelácia, región čistého vedomia ako rezíduum fenomenologickej redukcie potom predstavuje základnú pôdu poznania. Ak Husserl hovorí, že treba vyradit' generálnu tézu sveta, vyrovnat' sa s naivnost’ou prirodzeného postoja vrátane vedenia, ktoré z neho vychádza, a že prvou oblast'ou fenoménov je to, o čom nemáme mat' vopred nijakú mienku danú zvonka, teda prvou oblast'ou fenoménov je to, čo je nám vlastne nezrozumitel'né, ${ }^{11}$ podobne ani moderné a avantgardné obrazy a texty nemajú ${ }^{12}$ odkazovat' na realitu spočívajúcu mimo nich samých (reprezentovat', symbolizovat' či ilustrovat'), ktorá by pomáhala vysvetl'ovat' to, aký je ich zmysel. Takéto „prečiarkovanie“ či „,vypínanie“ reality sa teda deje aj v umení, kde k nemu dochádza $\mathrm{v}$ texte alebo na obraze. Mathauser si vyberá ako jeden z príkladov báseň Fráňu Šrámka Splav (1916), ktorá postupne prechádza od sna o stretnutí zamilovaných cez reflexiu vzt’ahu dvoch l'udí až k predstave „spomienky na stretnutie, keby k nemu došlo“. V básni sa teda „aj zhŕňa, aj vlastne odvoláva, splavuje všetko predchádzajúce, odníma $\mathrm{z}$ neho modus uskutočnenia - a sme opät' $\mathrm{v}$ tom istom fenoméne: nikde nie je jediné slovo dokladajúce stretnutie skutočné!“(Mathauser 2006, 141) Namiesto faktickosti pocit’ovania alebo okolností, za akých $\mathrm{k}$ stretnutiu dochádza, ktorým by mal podliehat' jeho zmysel, sa - naopak - zmysel udalosti „uvol'ňuje“, oslobodzuje a odhal'uje vo svojej čistej podstate.

Zastavme sa ešte pri výkone metodického gesta. Mathauser používa viacero jeho obmien: uvádza napríklad pojem vykol'ajenia, „odsávania“, odčítavania, všíma si dynamiku kladenia významov v diele a ich odvolávania, môže íst’ aj o situácie, pri ktorých sa stretávajú protichodné aspekty, rôzne tendencie, ktoré na seba narážajú, alebo sa križujú. Čo takýto postup spôsobuje? Ide o redukcie, ktoré pôsobia v rovine vnímania, ale následne aj o rozdiel medzi rôznymi druhmi, štatútmi predmetností - vecou a obrazom (artefaktom) -, na ktorý sa zameriava špeciálny výkon neutralizácie, takzvanej neutralitnej modifikácie. Výhodou umeleckého diela, respektíve umeleckej situácie je, že namiesto kroku „izolovania“, ku ktorému dochádza vo fenomenologickej redukcii, ked' odoberáme, čo k danosti veci nepatrí, môže byt', naopak, táto metóda

\footnotetext{
${ }^{11}$ Porov. napríklad Husserl $(2002,482)$.

${ }^{12}$ Ani v rovine znázorňovania, ani interpretovania.
} 
sériou viacerých krokov (redukcií) vedúcich ku „komplexnosti“, variabilnosti, ktorú môže rozvinút' práve situácia diela (Mathauser 1999, 39, 40).

Na rozdiel od predchádzajúceho príkladu z prvej časti tohto textu, ktorý zachytával vzt’ah medzi Jakobsonom a Husserlom, ktorý sa odvíjal najmä od Logických skúmaní, u Mathausera nachádzame okrem iného širší fenomenologický záber. Orientuje sa najmä na eidetiku Ideí, ${ }^{13}$ teda možnosti eidetickej redukcie, hoci sa na ňu ani neobmedzuje $\mathrm{v}$ prípade širšieho využitia fenomenologickej epoché. $Z$ toho vyplývajú dve tendencie, ktoré sa stretávajú v úsilí primerane zachytit' oblast' javenia fenoménov. Táto cesta uberania $\mathrm{z}$ reality vedie $\mathrm{k}$ poznávaniu $\mathrm{v}$ rámci čistej sféry podstát (v umení takisto k abstrakcii, absencii, „tichu“ a pod.), čoho ciel’om je odkrývat' skutočný, ,absolútny“ zmysel, ktorý je v bežnom živote i v teórii zakrytý nánosmi poznatkov, zvykov niečo tak a tak vnímat', určení, ktoré mu pripisujeme. Je tu však stále prítomná aj výzva fenomenológie vrátit' sa spät' $\mathrm{k}$ veciam samým, ktorú Mathauser spája so záujmom o takzvanú „vecnatost“" v umení, so snahou íst' až na „dreň entít“" (Mathauser 2006, 149), viazanost'ou na predmet $\mathrm{v}$ jeho vlastnom javení, a teda aj v jeho rôznych podobách. Toto vyprázdňovanie, odoberanie z reality, je preto len zdanlivou negáciou ${ }^{14}$ a pôsobí skôr ako otváranie nových možností skúmania. Výkon, technika, prax metódy vo fenomenológii a estetická skúsenost' sa tu vhodne dopíńajú. ${ }^{15}$

Pri tret’om príklade tohto textu, ktorý nadväzuje na teoretickú a recepčnú čast', chcem poukázat' na možné vzájomné pôsobenie medzi fenomenológiou a tvorbou v umení. Podoby istej tvorivej negácie, ktoré sú kritickou reakciou na spredmetňovanie, objektivizovanie, pričom však nevedú k úplnému vyprázdneniu, ničote, ale skôr uvolňujú akúsi dynamiku prázdna, totiž využije aj umenie nasledujúceho obdobia. Ako sa s týmto vyprázdňovaním vyrovnávajú umelci vo svojej konkrétnej tvorbe, možno sledovat' - hoci so svojbytným a kritickým prístupom k modernému a avantgardnému umeniu, ako aj s časovým posunom do posledných desat'ročí 20. storočia v koncepciách slovenských umelcov, ako boli Filko, Zavarský a Laky. Teoretik umenia Daniel Grúň súhrnne opisuje ich tvorbu ako videnie čistých očí, tvorbu čistého

\footnotetext{
${ }^{13}$ Spoločné prieniky v eidetike nachádza aj Holenstein (1976, 44 a n.).

${ }^{14}$ Ako hovorí Husserl: „Vlastne sme nič nestratili, ale získali sme celé absolútne bytie, to, aby sme správne rozumeli, v sebe skrýva všetku svetskú transcendenciu, ktorú v sebe ,konštituuje““ (Husserl 1976, 107, čes. 94).

${ }^{15}$ G. Černavin a A. Jampol'skaja poukazujú na paralely medzi „fenomenologickou praxou a praxou ostranenia“, ozvláštnenia, defamiliarizácie, ,technikou“ umenia u Šklovského. Celkovo sa dá povedat', že „Husserl nazýva estetickým vedomím alebo, estetickou intuíciou‘ zameranie na spôsob javenia, čo je v ,blízkom vztahu' (nahe verwandt) s fenomenologickou intuíciou“. Pritom možno sledovat' nielen zmenu postoja od toho, ,čo“ sa javí, k ,ako“ javeniu, ale aj potrebu opätovného návratu k onomu „,̌co“, resp. osciláciu medzi „čo“ a „ako“ javenia. V tejto súvislosti autori ukazujú, že „toto preblikávanie (flickering) postojov hrá kl’účovú rolu vo fenomenologickom obohatení zmyslu (Sinnbereicherung)“ (Chernavin, Yampolskaya 2019).
} 
umenia - vystavený biely priestor ako výsledok krajnej redukcie (Grún̆ 2019, 628 629). To, čo je v týchto inštaláciách bielych plôch intenzívnejšie prítomné ako v predchádzajúcich umeleckých iniciatívach pracujúcich takisto s bielymi plochami, je (popri tom, že sa odpútavali od zaužívaných schém vnímania, do ktorých nás tlačí faktická, doslova fyzická realita) aj dôsledné „preverovanie“ sociálnej reality. Sproblematizovanie familiárnej intersubjektívnej situácie vedie k odhaleniu jej neprehl'adnosti. Intenzívnym i skrytým spôsobom totiž do nej zasahujú ideológie, sociálno-politické schémy, skúsenosti manipulácie, kontroly prejavu, neslobody aj traumy vojnových konfliktov. ${ }^{16}$ Gesto umelca ako cezúra faktického časopriestorového a sociálneho sveta vyústuje do bielych plôch, ktoré sú, naopak, otvorené, slobodné a variabilné (Grúň 2020).

\section{Podoby metódy v spolupráci medzi fenomenológiou, štrukturalizmom a ume- leckou tvorbou}

V troch príkladoch, ktorým sme sa venovali, sa objavovali rôzne akcenty spolupráce a stupne explicitnosti, respektíve nepriamosti vz'ahu medzi fenomenológiou na jednej strane a štrukturalizmom (Jakobson), avantgardou a jej analýzou (Mathauser) a umeleckými iniciatívami na druhej strane (Filko, Zavarský, Laky). Tieto konvergencie nevyhnutne nastolujú aj otázku hraníc a metódy spoločnej platformy. Fenomenologická metóda tu bola prítomná pri zmene postoja i „,metodickom geste“, no pozrime sa na túto metarovinu, postavenie fenomenologickej metódy ešte raz. Ked’že vychádzame z fenomenologickej filozofie, otázka metódy je od začiatku klúčová. No zároveň aj v samom fenomenologickom hnutí možno pozorovat', že prináša viacero odpovedí, respektíve podnecuje viacero stratégií. Pri fenomenologickej redukcii je dôležité východisko, úvodná otázka, ktorá si potom vyžaduje príslušné metodologické riešenie, a to otvára príslušné fenomenologické pole javenia fenoménov a odhal'ovania modov ich daností (napríklad v matematike, psychológii, etike alebo estetike). ${ }^{17}$ Fenomenológia ( $\mathrm{v}$ rámci takzvanej filozofickej epoché) má za ciel' skúmat' predpoklady, schémy, anticipácie či viery, ktoré patria $\mathrm{k}$ prirodzenému postoju, respektíve aj $\mathrm{k}$ vedeckému postoju, ktorý sa na ňom zakladá. Redukcia umožňuje postavit' sa mimo generálnej tézy sveta, nebrat' ju do úvahy, no pozriet' sa na to, o akú danost' $v$ tom-ktorom prípade ide, $v$ akom skúsenostnom rámci sa nachádza príslušné pole (región) skúmania. Fenomenológia sa vracia k otázke metódy aj na záver svojho skúmania v takzvanej fenomenológii fenomenológie, v radikálnej sebareflexii, ktorá

\footnotetext{
${ }^{16}$ Tieto faktory boli spoluprítomné v celom umení 20. storočia, no v prípade spomínaných umelcov prevažuje scitlivenie na jednotlivé aspekty sociálnej reality ako reakcia na dlhodobú nemožnost' slobodnej tvorby.

${ }^{17}$ Porov. Loidolt (2020), Zahavi (2019). Ako upozorňuje Zahavi v texte o hraniciach epoché, pre d’alšie aplikácie fenomenológie, ktoré nemajú výlučne fillozofický záber, možno pracovat' len s istým rámcom fenomenologickej metódy (spomeňme napríklad etnológiu).
} 
rieši problém založenia samotnej fenomenológie. Inými slovami, komplexnost' metodologického prístupu vo fenomenológii vhodným spôsobom vyjadruje pojem ,responzívnosti“, ktorý otvára možnosti rôznych ciest a špecifických akcentov fenomenologického prístupu - od čisto deskriptívneho až po protonormatívny, ${ }^{18}$ od užšieho (napríklad estetického) až po širšie, transcendentálne uvažovanie, inými slovami od prístupu aplikovaného v skúsenostnom poli až po prístup zameraný na vnútorné otázky filozofie, respektíve fenomenológie samej.

V našom príklade sa metodická stratégia bezpredsudkovosti, redukovania, kritiky, premeny prirodzeného postoja či sprítomnenia fenoménu v primárnom popise ${ }^{19}$ využívali pri odhal'ovaní konštitutívnych vrstiev jazyka (poézie, príznakových a bezpríznakových slov) a spôsobov zobrazovania (desymbolizácia, redukcia na biely priestor). Podl’a Zdeňka Mathausera, ktorý sleduje vzt’ah susedstva fenomenológie a umenia, je ich vzájomná interferencia vel’mi funkčná, no nemožno ju ani preceňovat' a zbytočne racionalizovat', skôr ,,dobre pochopená fenomenológia sa nachyl'uje k lepšiemu chápaniu poézie (i vizuálneho umenia, J. V.) - a naopak“ (Mathauser 2006, 101). Mathauser hovorí o vzt'ahoch reverzibility, zvratnosti (2006, 145 - 158, 85), teda že fenomenológia poskytuje vhodné metodické postupy a umelecká tvorba zase exemplárnost', špecifickú rovinu skúsenosti umeleckého diela a vhodnú oblast' fenoménov (sem by sa dala zaradit' aj tvorba troch slovenských neoavantgardných umelcov). Toto opakované prehlbovanie metodologického uvažovania, ktoré nachádzame u Mathausera, sa dá spojit' práve s tým, čo sme označili za responzívny charakter metódy. Herman používa skromnejší koncept obmieňania tematiky medzi fenomenológiou a štrukturalizmom, uvedomujúc si rozdielne pole pôsobenia oboch prístupov. Vznikajú tak prirodzené prieniky v jednotlivých témach, no tie majú svoje hranice, ide teda len o čiastkové stretnutia. Holenstein, ktorého teoretická analýza je zase otvorená pre vzájomnú interferenciu, opisuje heuristickú spoluprácu a nachádza viacnásobné dopíňanie, vyplývajúce z konkrétneho dobového riešenia filozofických a lingvistických otázok.

\footnotetext{
${ }^{18}$ Ako na to upozorňujú B. Waldenfels a S. Loidolt pri svojom uvažovaní o d’alšom uplatnení fenomenologickej metódy napríklad v politickej a právnej teórii: „Kritická práca, ktorú môže fenomenológia spravit' napríklad pri uvažovaní o otázke rovnosti a emancipácie, teda spočíva v tom, že ich nebude chápat' ako abstraktné normatívne pojmy (čo by motivovalo určitú kritiku zvonka), ale že bude demonštrovat' a analyzovat' ich základný význam na skúsenostnej, niekedy protonormatívnej rovine“"(Loidolt 2020). Porov. aj D. Zahavi (2019). K možnostiam redukcie pri skúmaní hraničných fenoménov porov. napr. J. Vydrová (2015).

${ }^{19} \mathrm{P}$. Rezek, opierajúc sa o W. Biemela, používa takzvaný primárny popis: privolat' fenomén $\mathrm{k}$ nahliadnutiu. Tento opis sa týka odkrývania, odhal'ovania skôr než toho, čo je dané (a čo je doménou sekundárneho popisu). Porov. Rezek (2010, 14 a n.).
} 
Čo majú navyše tieto prieniky spoločné, je aj ich lokalizácia v regióne spätom s osobitným vztahom k určitej myšlienkovej tradícii. ${ }^{20}$ Práve tieto špecifiká naznačujú, kde môže pôsobit' fenomenológia v produktívnej spolupráci s inými disciplínami a kultúrnymi tradíciami a prečo sa skúmanie kontextu štrukturalizmu, fenomenológie a umeleckej tvorby v našej oblasti objavuje ako inšpiratívna téma, ktorá prekračuje čisto historiografický záznam alebo „vnútro-filozofický“ problém. ${ }^{21}$ Zároveň to poukazuje aj na nové možnosti fenomenológie, ktorá, pokial’ sa nezvrhne ,na epigónstvo singulárnych stanovísk“, bude môct' pokračovat' ako taký pohyb, ktorý bude zdrojom ,pôvodnej hybnej sily, schopnosti mobility a flexibility... plodný fenomenologický výskum môže kreatívne oživit' už zavedenú vedeckú prácu, pričom ju bude zároveň poháňat' vpred k novým otvoreným horizontom“. Túto potenciu a stratégiu nachádza práve vo vzt’ahu fenomenológie a estetiky Hans Rainer Sepp (2010, xxvii - xxviii).

Záverom tohto pohladu do genealógie fenomenológie $\mathrm{v}$ stredoeurópskom priestore teda je, že prieniky fenomenológie a pražského štrukturalizmu túto stratégiu v minulosti overili, a takisto tým pripravili inšpiratívnu pôdu pre fenomenológiu a nové možnosti skúmania a spolupráce s oblast’ou umeleckej tvorby.

\section{Literatúra}

Horizon (2016): Studies in Phenomenology. Special Issue: Traditions and Perspectives of the Phenomenological Movement in Central and Eastern Europe, 5 (1).

Filozofia, 61 (1), 2006, monotematické číslo k téme fenomenológie.

FULKA, J. (2017): Ruce a svět: Merleau-Ponty, gesto a znakový jazyk. Studie z aplikované lingvistiky, (1), $43-52$.

GRÚŇ, D. (2019): Úvaha o chýbaní. Biele práce Stana Filka a Mladena Stilinovića. In: Oskár Čepan a výtvarné umenie. VŠVU a Slovart, $624-637$.

GRÚN, D. (v tlači, 2020): Notes of a Belated Viewer. Revisiting White Space in White Space by Stano Filko, Miloš Laky and Ján Zavarský. In: White Space. Kontakt. The Art Collection. Vienna: Schlebrücke Editor.

HERMAN, D. (2014): Význam knihy Das literarische Kunstwerk Romana Ingardena pro českou literární teorii. In: O. Sládek (ed.): Český strukturalismus v diskusi. Brno, 120 - 128.

HOLENSTEIN, E. (1976): Linguistik, Semiotik, Hermeneutik. Plädoyers für eine strakturale Phänomenologie. Suhrkamp Verlag. ${ }^{22}$

\footnotetext{
${ }^{20}$ Mathauser v súvislosti s Mukařovským, Ingardenom a Losevom uvádza, že každý z nich „bol pôvodom spojený s jednou zo slovanských krajín a s tou či onou národnou tradíciou. Zároveň však všetkých troch oslovil všeobecný a vel'mi perspektívny prúd filozofického myslenia, Husserlova fenomenológia. Rozdielny však bol spôsob súžitia každého z nich s fenomenológiou“ (Mathauser 1999, 74).

${ }^{21}$ „Spolupráca sa nemá realizovat’ ako vnútro-fenomenologický alebo vnútro-filozofický dialóg, ale mala by zahŕňat' iné disciplíny a medzikultúrnu výmenu“ (Sepp 2010).

${ }^{22}$ Kapitola z Holensteinovej knihy Pražský strukturalismus jako odnož fenomenologického hnutí vyšla v českom preklade v knihe O. Sládek (ed.) (2014): Český strukturalismus v diskusi. Brno, 100 -119. Tam, kde sa nemecký a český text prekrývajú, odkazujeme na obe vydania.
} 
HUSSERL, E. (2002): Zur phänomenologischen Reduktion. Texte aus dem Nachlass (1926-1935). Zost. S. Luft. Dordrecht, Netherlands: Kluwer Academic Publishers.

HUSSERL, E. (1976): Ideen zu einer reinen Phänomenologie und phänomenologischen Philosophie. I. Halbband. Hrsg. K. Schuhmann. Den Haag: Martinus Nijhoff (čes. preklad A. Rettová, P. Urban. Praha: Oikoymenh 2004).

HUSSERL, E. (1966): Analysen zur passiven Synthesis. Aus Vorlesungs- und Forschungsmanuskripten, 1918 - 1926. Hrsg. M. Fleischer. The Hague, Netherlands: Martinus Nijhoff.

HUSSERL, E. (2010): Logická zkoumáni II/1. Zkoumání k fenomenologii a teorii poznání. Praha: Oikoymenh.

HUSSERL, E. (2014): Grenzprobleme der Phänomenologie. Analysen des Unbewusstseins und der Instinkte. Metaphysik. Späte Ethik (Texte aus dem Nachlass 1908 - 1937). R. Sowa - Th. Vongehr (eds.). New York: Springer. (Husserliana 42).

CHERNAVIN, G., YAMPOLSKAYA, A. (2019): ,Estrangement' in aesthetics and beyond: Russian formalism and phenomenological method. Continental Philosophy Review. Springer Netherlands. DOI: https://doi.org/10.1007/s11007-018-9454-8.

JAKOBSON, R. (1991): Lingvistická poetika. Bratislava: Tatran.

JAKONSON, R. (1995): Poetická funkce. Nakladatelství H\&H.

LIPTÁK, M. (2007): Čítanie v nápovedách. Ostium, 3 (4).

LIPTÁK, M. (2013): Možnosti umeleckej kritiky: Fenomenologická analýza. Trnava: Filozofická fakulta TU.

LOIDOLT, S. (v tlači, 2020): Order, Experience, and Critique. The Phenomenological Method in Political and Legal Theory. Continental Philosophy Review.

MATHAUSER, Z. (1999): Estetika racionálního zření. Praha: Nakladatelství Karolinum.

MATHAUSER, Z. (2006): Básnivé nápovédi Husserlovy fenomenologie. Praha: Filosofia

MERLEAU-PONTY, M. (2013): Fenomenologie vnímání. Preklad J. Čapek. Praha: Oikoymenh.

MERVART, J. (2013): Filosofický časopis mezi stalinismem a normalizací. Filosofický časopis. 60 let Filosofického časopisu, mimoriadne číslo, 1.

PEUCKER, H. (2008): Die Grundlagen der praktischen Intentionalität. Ein Beitrag zu Husserls Phänomenologie des Willens.[online]:

URL:<http://www.dgphil2008.de/fileadmin/download/Sektionsbeitraege/13-2_Peucker.pdf $>$.

REZEK, P. (2010): Tělo, věc a skutečnost. V uměni šedesátých a sedmdesátých let. Praha: Jan Placák - Ztichlá klika.

SEPP, H. R. (2010): Preface. In: H. R. Sepp, L. Embree (eds.): Handbook of Phenomenological Aesthetics. Dordrecht, Heidelberg, London, New York: Springer.

Studies in East European Thought 69 (1), 2017.

VYDROVÁ, J. (2015): Phänomenologie in den Abwandlungen der Reduktion und in der Fragestellung nach den Randphänomenen (der Geburt und des Todes). The Yearbook on History and Interpretation of Phenomenology 2015: New Generative Aspects in Contemporary Phenomenology. Frankfurt am Main: Peter Lang Edition, 75 - 87.

ZAHAVI, D. (2019): Applied phenomenology: Why it is safe to ignore the epoché. Continental Philosophy Review. Springer, 1 - 15. DOI: https://doi.org/10.1007/s11007-019-09463-y.

Tento text vznikol na Filozofickom ústave SAV v Bratislave ako súčast' riešenia grantovej úlohy VEGA č. 2/0110/18.

Jaroslava Vydrová

Filozofický ústav SAV

Klemensova 19

813640 Bratislava

e-mail: jaroslavavydrova@gmail.com

ORCID ID: https://orcid.org/0000-0001-6046-0074 